\title{
Time Constraint of Working Mothers - A Sociological Study
}

\author{
Sham Sun Nisa \\ Department of Sociology, University of Kashmir Srinagar India - 190006
}

\begin{abstract}
This paper highlights the working women's triple roles. First, she has to function as a wife, second as a mother and third as a worker. The question arises how efficiently can a working women function as a mother/wife at a home and a worker in the place of work. In an attempt to study these differences, the present study is carried out on children of working mothers, of different occupational categories. It intends to examine the relationship between mother's work status and family environment and its consequential effects on adjustment of their children.
\end{abstract}

Key Words: Working Women, Child Care, Domestic Chores, Kashmir Valley

\section{Introduction}

In today's world pursuing a specific occupation, the virtues of hard work, frugality, responsibility, steady work habits are all greatly valued. The need for security and recognition becomes closely associated with getting and keeping the job. The high prestige value of a good position in terms of job especially that which provides a handsome remuneration leads to rising aspirations which may result in a better quality of life. Thus work becomes an integral part of life both for men as well as for women. However, there is a strong belief that a woman's place is in the home with her children because of the societal norms. However, there is much more to be considered than just whether to stay at home with her children or not. There are many variables of the issues pressing on a mother in today's society. Economic, social and emotional issues combine to make a mother's choice whether to stay at home with her children or work outside the home, the hardest decision many women ever face.

Many women work simply because changes in the economy have made it necessary for many married women to work. Living costs, such as housing and food prices have risen. Thus, for most married couples or two parent families it is necessary to have two incomes to maintain the standard of living which was once possible to attain with a single wage-earner. For many married women the income from the husband alone is not enough to support the family, thus there is a need for the mother to work and ease some of the financial burden of the family. Many families cannot feed their babies unless mother's outside work. Many researchers believe that as the cost of living continues to rise, many more families will be forced to have both parents work outside homes.

\section{Women and Work}

As far as "women and work" is concerned there has been a significant increase in women's participation in the work force not withstanding their contribution at the home front. This is more significant in view of generally held view that whether it is professional field or home or anywhere, efficiency of women is comparatively higher than their male counterparts. ${ }^{1}$

Looking back, women have primarily been associated with the home and men with the world of work. As home makers women are expected to look after the domestic front. This involvement however, varies in different socio-economic conditions and in different regions. Most women understand their role and do have a forward looking ambition. They are satisfied if men understand their aspirations ignoring traditional and conservative attitude regarding involvement of women in gainful employment. Women in the context of development: cultural, social, political, economic and psychological, have been restrained in their quest for selfhood and autonomy. It is only recently that they have started coming out of their seclusions and are marching ahead in the world of work. ${ }^{2}$

There are evidences to show that the traditional view regarding the place and role of women is slowly losing ground in contemporary society. The process has been generated and aided by a variety of factors which are operating simultaneously. Increasing opportunities for modern education, greater geographical and occupational mobility and the emergence of new economic patterns may be cited as a few possible factors for such a change. This however, should not be viewed as replacement of tradition by modernity; rather it should be treated as

\footnotetext{
${ }^{1}$ Sircar Basobi. 1994. "working mothers and adolescent wellbeing” Common wealth publishers, New Delhi

${ }^{2}$ Singh, k. p. 1972. "Career and family-women: Two Roles”, Indian Journal of Social work.
} 
modernized tradition, failing which it would lead to "modernity" becoming rootless and deficient. The ongoing movements on women's upliftment should thus, focus on women's development in every respect by not destroying the very basis of women's structure. That is to say that 'women should join work force' is emphasized, but by not letting their role in the home front pushed in a relegated position.

\section{Women's Role - As a Mother}

Women, as a social category, perform multiple roles. Certain types of roles have been universally recognized and socially institutionalized. The biological woman is the product of nature but the socio-cultural woman is structurally created and conditioned. The physical differentiation between man and woman necessitates certain social arrangements for procreation and rearing of children. A human child needs prolonged care during infancy in contrast to other animals.

As soon as a woman attains the status of 'mother' she entails additional responsibility. A woman, as a mother, has a unique place in our society. Out of the two parents, the mother's role is greater and more significant. She is the preserver of the 'cultural traditions' and socializer of young generation and inculcates traditional values and norms to the young generation. Apart from these she also plays a role in the development of the emotional psychology of the child.

Home environment, though a contributory effort of both the parents in the family and later added by the efforts of children, a major share of it however, results from the contribution of the mother. Mother is understood to be a prime factor in the development of the child as she spends most of her time satisfying the physical, mental and moral needs of the child. The influence of the mother on her child is particularly important. Mother's influence may lay the foundation of a happy and prosperous life or it may turn it towards disaster. Mother is the most important socializing agent as the child receives from her valuable training of discipline and self-control.

In the study of individual- group interaction, the mother is the first and foremost in its influence. It is the mother to whom the child has his first social relationships in which and through which he acquires and organizes his experiences. No other institution has so significant a role in the transition of individual to a person as is of the mother's. In the first year of life it is the mother's lap from which a child's "humanizing" process begins. Mother is said to be "the eternal school of social virtues" 4

\section{Working Women and Child Development}

The substantial increase in the women's employment over the past has significantly affected the socio psychological and family processes having a bearing on the children in home as it is the married women who face the challenges and problems in employment sector. For employed women there may be a number of reasons underlying the need to work but the effect of mothers' employment on the well--being of their children does evoke special interest. When a woman takes up a job outside her home she has to function as a wife, a mother and as a worker. This places additional responsibility on her requiring the skill as well as capabilities of acceptance and adjustment to the change brought about by the multiplicity of roles. Out-of-home work by mothers' was analytically important for establishing whether it did or did not negatively influence the normative patterns of family life.

The women's continuing role of child rearing and home management suffers by entering into job life as it adversely affects the home-front. There follows a remarkable change in family structure and family environment. ${ }^{14}$ Today more mothers work outside their home than before. This affects children depending partly upon the provisions made for their care. It is assumed that the child usually feels lonely and unhappy when the mother is away for a major part of the day. ${ }^{5}$

In families where mother works, there is a greater possibility that the home duties will get neglected or postponed or transferred and there are fewer opportunities for social life and recreation with the family. Children of such families are more expected to share in the household activities as compared to children of non-working mothers. It has been observed that young children are more affected by the mother's employment than older children.

The mother's reason for working and her attitude towards work has a significant bearing on her role as a mother. Because employment does not fit into the cultural stereotype of "mother"; she may feel guilty about being away from home, especially if working is not motivated by economic necessity. The newborn infant comes into the world with no inherited predispositions, but rather with a mind as a "blank slate" that is gradually filled with ideas, concepts, and knowledge from experiences in the world. The early experiences, particularly how children are raised and educated, shapes the direction of a child's life. This statement is sufficient to realise

\footnotetext{
${ }^{3}$ Menaghan, E.G., \& Parcel, T.L. 1990."Parental Employment and Family Life: Research in the 1980s." Journal of Marriage and the Family. ${ }^{4}$ Opcit. 1994. Basobi Sircar.
} 
the importance of guidance and socialization for a child. And who can be a better socializer and a better guide than a mother?

Many social psychologists, William McDougall, John B. Watson, E.A. Ross, Floyd Allport, introduced the concept of attachment. They proposed that infants and young children form emotional bonds to their care-givers because throughout human evolutionary history close attachments to mother promoted the survival of defenseless children. Attachment is a psychological bond between an infant and her or his primary care giver, i.e. the mother. Crying and smiling bring infants in contact with care givers and are called attachment behaviours. Attachment provides a secure emotional base from which mature relationship develops. Research shows that inadequate attachment impedes social and emotional development throughout life. ${ }^{5}$

Researchers have shown that an infant cannot develop physically as well as mentally if he is not receiving the message of attachment and love. It is well known that no one can take care of a child as a mother can. The first agent of socialization is the mother for a child. It is saying that 'the family revolves round the child and the child revolves round the mother'. Phil Ponce rightly said that "the good quality or the best quality child care centers do not provide what a mother provides". 6

Child rearing has posed the biggest challenge to the working mothers. The problem starts with preschool care when the mother leaves the infant with a relative or a maid, or puts him/her in a crèche. Unlike in the good old joint families, the absence of elderly presence in the modern nuclear families leaves the working mother with no option but to leave the child in a day care centers. Here comes the role of a crèche or play school to substitute the tender care of home for a blooming child much to the relief of young working mothers. ${ }^{7}$ Some mothers are hiring the services of servants to look after their children. Baby sitters are usually paid to watch, play with and care for the children. But the purpose would be served only if the children received their sitters' full attention.

\section{Working Women in Kashmir}

In the past, the lives of the people were simple. The economy was agrarian. People lived simple lives and religion held sway over their lives. It was generally believed that the ideal place for a woman from birth till death is the family household. Consequently, they were confined to their homes throughout their lives and were hardly exposed to outside world. Women were also supposed to be completely dependent on their men, fathers and husbands or brothers. Men used to earn and spend their money while women worked within the family household. In traditional society, women's role was limited to the family. Since she was the bearer of the children, she was fully occupied with her role as a mother and home maker.

In traditional times women spend most of their time with their children. During infancy period children need their mothers. In the past mother was present at the time when the child needs her particularly during stress and strain the children needs someone to rely upon. He/she found himself/herself in the loving care of his/her mother. Whenever such children face some upheavals in life, their mother was there for support and to share their burden. Naturally the life of such children was free from emotional upheavals and rarely suffered psychic problems.

There was also a change in the outlook of people. People began to seek earning women as daughter's-in-laws and/or as wives. As the economies of those who had working women as their wives or daughter-in-laws improved largely, the trend changed. There was a high demand for working women and those women who did not work/earn were not much sought in marriages. The result was late marriages as the girls began to get higher education for employment. It was during this period that electronic media too made its entry into this secluded valley and there was an impact of western culture in the valley. Privatization of the insurance companies, banks \& finance companies had its own impact: many jobs were made available to youth and girls were particularly encouraged by these companies to join. There was a complete overhaul of the society. The traditional and cultural values were lost and the role of family changed completely. There were new aspirations, new goals, new themes and new aims. All this happened because woman broke the traditional roles and came out of her home.

The worst sufferer of all this was the child as there was no one to look after him. He was left alone to make his way in this world. The love and affection which a child was showered within the traditional Kashmiri society were lost. Today's child appears to be lonely without any support. He has no one to confide in. In foreign societies, the people have developed means to take care of their children, but all these facilities/experiences are lacking in Kashmir.

\footnotetext{
5 Sinha, Pupsa. 1988. "Role conflict among working women” Janaki Prakashan Publishers, New Delhi.

${ }^{6}$ Ponce, Phil, 1997. "A Real Mother in the Modern World”. A report on child care on brain development leads to a call for better child care.

${ }^{7}$ Luecken, Linda, "A Duke University study on stress in working moms" Veteran of the department of psychiatry at Duke University Medical Center in Durham
} 
The condition of women in Kashmir started undergoing change in the early decades of twentieth century according to experts. Factors like emerging political consciousness, improvement in the means of transportation and communication, spread of formal education and socio-cultural awakening created an environment in which women tried to access their position in the society. Thus, in the changing scenario women belonging to all classes, groups and communities started coming out of their homes for the attainment of formal education and even taking up careers in different governmental and non-governmental organizations. Their participation is also found in social fields, welfare activities administrative services and other bureaucratic jobs. They are contesting elections and participating in the deliberations of state legislatures. In short, they have made their presence in every field of life.

This, in turn, creates problems for the 'family organization' which is the basic institution of the society. For Kashmiri women these substantial changes have given new challenging roles. Apart from the motherhood and domestic work, they have to undertake an active role in economic organization. Because of outside as well as domestic work they have not much time to spend with their children; this affects the family organization badly. Working women have less time to look after their children, to attend to their needs and to chastise them when they go wrong.

\section{Methodology}

The area for this study was the Srinagar City in the Srinagar District of the Kashmir Valley. The choice of Srinagar city as the universe of the study was made because Srinagar is the biggest commercial centre of J\&K State and has the best possible cross-section of white collar and other office-based employees in the state.

The respondents for the study were those mothers who were working outside homes and leave their children (from the age-group of 04months-04years) on the mercy of unnatural resources. One hundred respondents (mothers') were chosen as the sample for the study by random sampling. During collection of data various research tools were used such as interview and observation method.

\section{Results and Discussion}

Children need always their mothers and there is no need of clarification because everyone is born of a mother and they can understand it in a better way. Love and affection are the important psychological needs of a child. If the child feels he is not loved or is unwanted or if the emotional identification with the parents is disrupted, the growing child may seek substitute companionship or may pass through a period of grave insecurity, frustration and resentment even hatred. In the above few questions, the researcher tried to elicit information from the Working mothers whether they were able to give requisite companionship to their children and satisfied their emotional needs, the researcher found that the situation was grim.

Tab. 1 Mothers need during the day

\begin{tabular}{|l|c|c|}
\hline \multicolumn{1}{|c|}{ Responses } & Number & \%age \\
\hline Yes & 97 & 97.00 \\
\hline No & 02 & 02.00 \\
\hline Indifferent & 01 & 01.00 \\
\hline Total & $\mathbf{1 0 0}$ & $\mathbf{1 0 0}$ \\
\hline
\end{tabular}

As is evident from the tab. 1, Majority i.e. 97 percent respondents informed that their children needed them during the day as nobody can be a substitute for the mother, 02 percent informed that they (children) did not needed them and 01 percent respondent was indifferent in her response.

Tab.2 Reasons behind the mothers need during the day

\begin{tabular}{|l|c|c|}
\hline \multicolumn{1}{|c|}{ Reasons } & Number & \%age \\
\hline Can feed the child properly & 09 & 9.26 \\
\hline Can look after him properly & 05 & 05.15 \\
\hline Others cannot take care of a child as a mother can & 44 & 45.36 \\
\hline Children need mothers always & 39 & 40.23 \\
\hline Total & $\mathbf{9 7}$ & $\mathbf{1 0 0}$ \\
\hline
\end{tabular}

As shown in tab.2, majority i.e. 45.36 percent mothers thought that others could not take care of children as mothers' could, 40.23 percent replied that children need mothers always; 9.26 percent respondents reported that they could feed them (children) properly and 5.15 percent replied that they could look after them properly.

The above two tables clearly reveal that children need their mothers during the day time when they are at office. Though they provided various reasons, the fact remains undisputable: that there is a void in the life of a child which can be filled only by a mother. 
40.23 percent mothers (39 out of 97) gave a simple reason for the child needing a mother during the day time: that the children needed mothers always. On its face, it appears to be the simplest answer, but it has a sea deep depth in it: that there is an unbreakable bond between the two - that must remain intact.

\section{Under the shadow of compassionate mother}

Presence is the best way of tucking love into pockets of time, working mothers should understand how to make their presence qualitatively meaningful. The lowest level of meaningful presence is mental closeness: Letting the person know that you are thinking about him even though you are away. A person may not be physically close to you but you can have them in your thoughts. This is an important way of communicating the message of presence. A few questions were asked to find out whether, after returning from work, a mother could spare time for her children or not.

Tab.3 Attention to the child after returning from the office

\begin{tabular}{|l|c|c|}
\hline \multicolumn{1}{|c|}{ Responses } & Number & \%age \\
\hline Yes & 06 & 06.00 \\
\hline No & 88 & 88.00 \\
\hline sometimes & 06 & 06.00 \\
\hline Total & $\mathbf{1 0 0}$ & $\mathbf{1 0 0}$ \\
\hline
\end{tabular}

As is evident from the analysis of the tab. 3 that majority of the respondents i.e. 88 percent, after returning from office were not in a position to attend their children, 6 percent respondents attended their children and 6 percent respondents were sometimes in a position to attend children after returning from the office.

Tab.4 Reasons for inattention towards the children

\begin{tabular}{|l|c|c|}
\hline \multicolumn{1}{|c|}{ Reasons } & Number & \%age \\
\hline Because of fatigue & 46 & 48.94 \\
\hline Because of domestic duties & 21 & 22.34 \\
\hline Sufficient time is not available & 27 & 28.72 \\
\hline Any other reason & None & 00 \\
\hline Total & $\mathbf{9 4}$ & $\mathbf{1 0 0}$ \\
\hline
\end{tabular}

When asked the reasons for not being able to look after their children, when they had returned from their office, 48.94 percent respondents replied that fatigue was the reason, 22.34 percent had to perform domestic duties and 28.72 percent simply lacked time.

The responses to these questions reveal that it is very difficult for the working women to devote attention to their children properly. Such inattention may create the feeling of being unwanted. Under such circumstances a child may develop bad habits. He might became an introvert and turn to a bad company for solace. And psychologists tell us that such things are the causes of delinquency.

Tab.5 Time spend by mothers' with the children

\begin{tabular}{|l|c|c|}
\hline \multicolumn{1}{|c|}{ Responses } & Number & \%age \\
\hline Yes & 04 & 04.00 \\
\hline No & 96 & 96.00 \\
\hline Indifferent & None & 00 \\
\hline Total & $\mathbf{1 0 0}$ & $\mathbf{1 0 0}$ \\
\hline
\end{tabular}

As shown in the analysis (Tab.5), majority of the respondents i.e. 96 percent did not get sufficient time to attend to their children while 04 percent respondents were satisfied with the time they spend with their children.

Tab.6 Reasons for not spending sufficient time with the children

\begin{tabular}{|l|c|c|}
\hline \multicolumn{1}{|c|}{ Reasons } & Number & \%age \\
\hline Stay outside home & 66 & 68.75 \\
\hline Have to attend domestic duties & 23 & 23.95 \\
\hline $\begin{array}{l}\text { After returning back are not in a position to attend } \\
\text { children }\end{array}$ & 07 & 7.30 \\
\hline Any other reason. & None & 00 \\
\hline Total & $\mathbf{9 6}$ & $\mathbf{1 0 0}$ \\
\hline
\end{tabular}

As it is evident from the (Tab.6) 68.75 percent had to stay outside homes for major part of the day, 23.95 percent respondents reported that they had to attend domestic duties after returning from the office and 7.30 percent respondents were not in a position to attend to their children after returning from office. 
Tab.7 Mothers' satisfaction for spending time with the children

\begin{tabular}{|l|c|c|}
\hline \multicolumn{1}{|c|}{ Responses } & Number & \%age \\
\hline Yes & 17 & 17.00 \\
\hline No & 76 & 76.00 \\
\hline To some extent & 07 & 07.00 \\
\hline Total & $\mathbf{1 0 0}$ & $\mathbf{1 0 0}$ \\
\hline
\end{tabular}

As is evident from the tab.7 regarding time spend by mothers with their children 17 percent respondents were satisfied. There were 76 percent respondents who were not satisfied whereas 7 percent respondents were not clear in their responses. Nobody can deny that working women have to shoulder a lot of responsibilities. As the time available for everyone is fixed, a large chunk of the working women's time is spend on her job, which leaves her short time for her children.

As recorded above most of the women were not satisfied with the time spend with their children, which makes us to realize the gravity of the problem.

Tab.8 Time leaving for office

\begin{tabular}{|l|c|c|}
\hline \multicolumn{1}{|c|}{ Responses } & Number & \%age \\
\hline $8 \mathrm{am}$ & 06 & 06.00 \\
\hline $9 \mathrm{am}$ & 87 & 87.00 \\
\hline $10 \mathrm{am}$ & 07 & 07.00 \\
\hline Total & $\mathbf{1 0 0}$ & $\mathbf{1 0 0}$ \\
\hline
\end{tabular}

As is depicted in the Tab.8, majority of the respondents i.e. 87 percent leave for office at $9 \mathrm{am}, 7$ percent respondents leave for office at 10 am while 6 percent at $8 \mathrm{am}$.

Tab.9 Preparation for leaving for the office

\begin{tabular}{|l|c|c|}
\hline \multicolumn{1}{|c|}{ Response } & Number & \% age \\
\hline $7 \mathrm{am}$ & 15 & 15.00 \\
\hline $8 \mathrm{am}$ & 81 & 81.00 \\
\hline $9 \mathrm{am}$ & 04 & 04.00 \\
\hline Total & $\mathbf{1 0 0}$ & $\mathbf{1 0 0}$ \\
\hline
\end{tabular}

Majority of the respondents' i.e. 81 percent started preparing for office at 8 am. The other respondents' 15 percent and 4 percent prepared themselves for office at $7 \mathrm{am}$ and at $9 \mathrm{am}$ respectively. It depends on the nature of job and distance of place. The morning time is essential for a child. He had to be dressed, diapered, feed etc. Some mothers would leave home when their children were asleep. It can be inferred that such children would feel disgusted when they would not find their mothers around when they have got up from sleep.

The responses to the above set of time related questions makes it clear that going to and preparing for office leaves but short span of time in the hands of working women which might affect the physical and mental development of the child. Most of the working women start preparing for office from very early in the morning. Obviously, they would not be able to attend to their children even if they (children) were calling for the same. And many a time - the researcher observed during the course of the study - the children would be deliberately taken away during the time their mothers were preparing for their office. A child usually cries for attention when he sees his mother indifferently preparing for office. This indifference on the part of their mothers would be hard upon the psyche of these children.

Tab.10 Respondents satisfaction to the performance of mothering role

\begin{tabular}{|l|c|c|}
\hline \multicolumn{1}{|c|}{ Responses } & Number & \%age \\
\hline Yes & 46 & 46.00 \\
\hline No & 51 & 51.00 \\
\hline To some extent & 03 & 03.00 \\
\hline Total & $\mathbf{1 0 0}$ & $\mathbf{1 0 0}$ \\
\hline
\end{tabular}

In connection with the performance of mothering role 46 percent of the respondents were satisfied with the performance of mothering role while 51 percent of the respondents were not satisfied and 03 percent were satisfied only to some extent with the performance of their mothering roles. Most of the women have not yet learned to cope up with their dual responsibilities, but with the passage of time things might change and mothers would learn to do justice with their dual roles. 


\section{Conclusion}

In our society the care and bringing up of children is considered primarily the responsibility of the mother. Sometimes the decision to take up employment depends upon this critical factor. Bringing up of children is a difficult job. Home keeping and child rearing is almost a complete profession and working mother can only pursue it successfully if she gets a close co-operation from her husband or in-laws. In case desired cooperation is not available, she fails to provide an environment of affection, protection and security to her child. Being tired of the outside work she gets irritated and out of irritation punishes her child unnecessarily. Sometimes they suffer from a sense of guilt because they feel that their mothers neglect them because of their outside work.

Majority of the respondents i.e. 96 percent confessed that they did not get sufficient time to spend with their children. The problem was more acute when the children are not going to school. It transpired that sometimes it was the respondents' in-laws, sometimes it was the respondents' parents and sometimes it was the servant/maid who looked after such children. Now the problem is whether these (other people) take same pains as the mothers do or not? The answer is clear "No". For the proper care of a child there is need of emotional attachment. And others' have not such attachment with a child as a mother has.

Even when the mothers return from the office majority i.e., 94 percent are not in a position to attend their children. As it is evident that due to various reasons, they are either fatigued, have to attend domestic chores or simply do not have time. These things would definitely affect the child. A relationship of communion would not be established. Therefore, the child would not receive from his mother which he would have if he were to live in the company of his mother. A child-mother interaction unwittingly transfers to child the hidden cultural traits of mother. He is imbued with the values, norms and traditionally held folkways. When this interaction is lacking, the child would be deprived of these blessings.

Majority of the mothers were not satisfied with the performance of their mother roles. On the ultimate analysis 76 percent respondents confessed that they were not satisfied with the time they spend with their children. The findings lead the researcher to conclude that the working mothers are not satisfied with the performance of their mother roles. They are aware of the fact that their children are not getting their (mothers) proper attention.

The analysis revealed that the mothers' presence is necessary for a child's physical as well as mental development and in her absence the problems are inevitable. However, these are not insurmountable problems. By proper guidance and expert applications of good methods, these problems could be solved. The corresponding infrastructure needs to be developed to the level compatible with culture of working women. This would involve establishment of crèches, day care centers etc. The people of Kashmir are averse to keeping servants at homes, making the working women more irksome. Governmental efforts are also needed. Legislation needs to be made in this direction. Working women should be made entitled to more leaves/holidays (with safeguards that they might not misuse the provision) and should not be posted at far off places.

Therefore, the things need to be re-adjusted. When a woman takes the plunge, she should realize that the traditional ways would not work, she has got to change her life style and adapt to the new challenges and shed the shackles which keep her bound to the hearth. A woman, however, is not an isolated entity but is the infinitesimal part of a larger whole. A change in the womenfolk alone would not suffice - the society as a whole has to bend to accommodate her transformed role. For preserving the complex structure of the society, its each and every part must get re-aligned; otherwise it would buckle under the unbalanced strain and give way to chaos.

\section{References}

[1]. Aggarwal, J.C. and Aggarwal, S.P. 1994. "Women's education in India". Concept publishing house, New Delhi.

[2]. Ashraf, Ara Talat. 1992. "Muslim Women in changing perspective" Common wealth publishers, New Delhi.

[3]. Chakraborty, K. 1995. "The conflicting worlds of working mothers" Calcutta publishers press.

[4]. Chris, Jains. 1982. "The sociology of childhood" Bastford academics and education ltd.

[5]. Chodorow, N. 1978. "The reproduction of mothering" University of California press, Berkeley.

[6]. Chandra, Jai Shree 1993. "Women and child" Rawat publications, New Delhi.

[7]. Kuzma, K. 1980. "Working mothers" Start ford press, Los Angeles.

[8]. Kapur, P. 1970. "Marriage and working women in India" Vikas publishing house, New Delhi.

[9]. Myrdal, A. Klein. 1968. "Women's two roles” Routledge London. 